University of Wollongong

Research Online

Faculty of Law, Humanities and the Arts Papers (Archive)

$1-1-2013$

\title{
Moving forward on joint development in the South China Sea
}

\author{
Robert Beckman \\ National University of Singapore, lawbeckm@nus.edu.sg \\ Clive Schofield \\ University of Wollongong, clives@uow.edu.au \\ Ian Townsend-Gault \\ University of British Columbia, itgault@law.ubc.ca \\ Tara Davenport \\ National University of Singapore \\ Leonardo Bernard \\ National University of Singapore
}

Follow this and additional works at: https://ro.uow.edu.au/lhapapers

Part of the Arts and Humanities Commons, and the Law Commons 


\title{
Moving forward on joint development in the South China Sea
}

\author{
Abstract \\ The examination of the factors that facilitated the conclusion of joint development arrangements in Asia \\ in Chapter 11 has demonstrated that there remain considerable obstacles before joint development in the \\ South China Sea can be discussed in a serious and meaningful manner. The following recommendations \\ set out steps which the claimants and, in certain circumstances, other relevant stakeholders, can take to \\ move towards a situation where joint development is a feasible dispute settlement option.

\section{Keywords} \\ joint, development, sea, forward, moving, south, china \\ Disciplines \\ Arts and Humanities | Law

\section{Publication Details} \\ Beckman, R., Schofield, C., Townsend-Gault, I., Davenport, T. and Bernard, L. (2013). Moving forward on \\ joint development in the South China Sea. In R. Beckman, I. Townsend-Gault, C. Schofield, T. Davenport \\ and L. Bernard (Eds.), Beyond Territorial Disputes in the South China Sea: Legal Frameworks for the Joint \\ Development of Hydrocarbon Resources (pp. 312-331). United Kingdom: Edward Elgar.
}




\title{
CHAPTER 12:
}

\section{MOVING FORWARD ON JOINT DEVELOPMENT IN THE SOUTH CHINA SEA}

\author{
Robert Beckman, Clive Schofield, Ian Townsend-Gault, Tara Davenport and Leonardo Bernard
}

The examination of the factors that facilitated the conclusion of joint development arrangements in Asia also demonstrated that there remain considerable obstacles before joint development in the South China Sea can be discussed in a serious and meaningful manner. The following recommendations set out steps which the claimants and in certain circumstances, other relevant stakeholders, can take to move towards a situation where joint development is a feasible dispute settlement option.

\section{Creating an Atmosphere Conducive to Joint Development}

One of the main lessons learned from the existing joint development arrangements in Asia is that two conditions are necessary before there can be serious discussions on joint development arrangements. First, joint development arrangements tend to be concluded in periods where good relations existed amongst the relevant parties. Second, the parties must have the political will to make decisions which may face opposition within their countries.

Therefore, steps must first be taken to build confidence and trust among the claimants, to reinforce the underlying rationale for joint development and articulate the advantages of pursuing this option to as wide an audience as possible. On this basis the political will that is crucial to 
pursue discussions on joint development may be more readily engendered. There are a number of steps which can be taken.

\section{A. Decide on Appropriate Institutional Frameworks for Discussion and Negotiations}

There is a lack of agreement on the appropriate institutional framework for discussion and negotiations on the South China Sea issues. There appears to be a lack of agreement between claimants on the forum where the South China Sea issues should be discussed and on who should be included in the discussions. The confusion on the proper forum is exacerbated by China's insistence that sovereignty disputes and competing claims be discussed bilaterally between individual claimants and by the actions of some ASEAN claimants to organise conferences and workshops which appear to be intended to internationalise the issues. There also seems to be some division on the role of ASEAN in the Spratly Islands disputes and on the role of 'Track Two’ discussions.

It is suggested that ASEAN can provide a forum for discussion between the claimants without it becoming a dispute between the ASEAN claimants and China. In any case, there is little likelihood that ASEAN will have a common position since the non-claimant Members have different priorities and interests and, as a result, view the issues differently than the claimants. Moreover, there appear to be differences even among ASEAN claimants on some issues (it should be noted that the Philippines and China both formally protested the joint submission of 
Malaysia and Viet Nam on their extended continental shelf). ${ }^{1}$ The counterpoint here, though, is that during discussions between China and ASEAN, non-claimant States such as Indonesia and Singapore have the potential to assist in helping find areas of common agreement among the claimants and help bring them together.

The Workshops on Managing Potential Conflicts in the South China Sea in the 1990s demonstrated that discussions and workshops at the 'Track Two' level can play an important role. ' 'Track Two' meetings are between non-government experts and government officials who attend in their personal capacity. This makes it much easier to discuss sensitive issues and brainstorm about possible solutions. It also enhances understanding and builds trust.

\section{B. Implement the 2002 DOC and Work toward Adoption of a COC}

\footnotetext{
${ }^{1}$ Commission on the Limits of the Continental Shelf [CLCS], Submissions to the Commission: Joint Submission by Malaysia and the Socialist Republic of Viet Nam (2009) CLCS.33.2009.LOS, The Joint Submission of Malaysia and Viet Nam, as well as the Communications submitted to the UN Secretary-General by China, Malaysia, the Philippines, Viet Nam and Indonesia with regard to the Joint Submission of Malaysia and Viet Nam, are available online: CLCS < http://www.un.org/Depts/los/clcs_new/submissions_files/submission_mysvnm_33_2009.htm>.

${ }^{2}$ The South China Sea Workshop (the Workshop Process) was an initiative first undertaken in 1990, fronted by Indonesia's Hasjim Djalal, which sought to bring together ASEAN States on an informal basis to facilitate dialogue on various issues in the South China Sea and find ways to manage potential conflict in the area. The First Workshop Process was conducted in Bali in 1990 with only six ASEAN-State participants (Brunei, Indonesia, Malaysia, Philippines, Singapore and Thailand). At a second meeting in Bandung in 1991 non-ASEAN participants were also invited, including China, Laos, Taiwan and Viet Nam. The Workshop Process has continued to be held annually in Indonesia since 1990 and has had developed considerably since its early meetings.
} 
The 2002 ASEAN-China DOC was an important milestone as it established a series of conflict avoidance mechanisms such as the holding of dialogues and undertaking co-operative activities designed to build trust and confidence between Parties. ${ }^{3}$ The parties also agreed to exercise selfrestraint in the conduct of activities that would complicate or escalate disputes and affect peace and stability. Few concrete steps have, however, been taken towards realising the confidencebuilding measures outlined in the DOC.

Discussions are presently ongoing on implementing the DOC and in July 2011, Guidelines on the Implementation of the DOC were adopted. ${ }^{4}$ This is to be welcomed and in particular, efforts and discussions on how to implement the co-operative arrangements in the DOC should be continued. The co-operative activities which the Parties are encouraged to undertake are marine environmental protection, marine scientific research, safety of navigation, communication at sea, search and rescue operations as well as combating transnational crime. These are arguably less controversial activities than joint development of hydrocarbon resources and hence, may be easier to reach agreement on. Such small incremental steps such as these will help foster the good will and trust necessary for discussions on joint development.

${ }^{3} 2002$ Declaration on the Conduct of Parties in the South China Sea, signed at the $8^{\text {th }}$ ASEAN Summit on 4 November 2002 in Phnom Penh, Cambodia by the Foreign Ministers of ASEAN and the People's Republic of China, online: CIL Documents Database < http://cil.nus.edu.sg/2002/2002-declaration-on-the-conduct-of-parties-inthe-south-china-sea-signed-on-4-november-2002-in-phnom-penh-cambodia-by-the-foreign-ministers/>.

${ }^{4}$ ASEAN, 'Guidelines on the Implementation of the DOC', online: ASEAN Secretariat

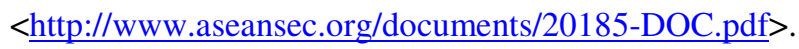


The parties have also agreed to work toward the adoption of a legally binding code of conduct (COC) for the South China Sea. The ASEAN member States are attempting to reach a general consensus on the principles to be contained in the $\mathrm{COC}$, after which they will enter into discussions with China, although the possibility of this being concluded in the immediate future is slim. ${ }^{5}$ It is hoped that the efforts to implement the DOC and reach agreement on a COC will reduce tensions and contribute to the creation of trust among the claimants as such trust is a precondition for serious discussions on joint development arrangements.

\section{Better Management of Domestic Politics and Nationalistic Rhetoric}

The Spratly Islands have become potent symbols of nationalism for the populations of the claimants. Accordingly, the public often perceives its Government as weak if it fails to aggressively assert its claims over the Spratly Islands. For example, while the international community perceives China as aggressively protecting its claims in the South China Sea, the Chinese people, particularly the netizens, often criticize their Government for not adequately asserting its position. ${ }^{6}$

There is a natural tendency for Governments to take actions and make decisions based on prevailing domestic politics or sentiments. This is dangerous, as not only does it further inflame national sentiments and emotions, it makes it difficult for the claimants to make reasonable

\footnotetext{
${ }^{5}$ Euan Graham, 'ASEAN Code of Conduct could avert South China Sea storm', The Global Times (1 July 2012), online: The Global Times <http://www.globaltimes.cn/content/718255.shtml>.

${ }^{6}$ International Crisis Group, 'Stirring up the South China Sea (I)', Asia Report No 223 (23 April 2012), at 26-27, online: International Crisis Group <http://www.crisisgroup.org/en/regions/asia/north-east-asia/china.aspx> $>$.
} 
compromises in international negotiations without being accused of surrendering their sovereignty. This is a major obstacle to any joint development agreement in the South China Sea (and any peaceful settlement of the disputes for that matter).

Accordingly, the Governments of the claimants and the media should make a serious effort to manage domestic politics and tone down nationalistic rhetoric associated with the claims to the Spratly Islands. First, Governments and the media should refrain from stoking national sentiments when incidents occur which are perceived as a threat to national sovereignty. Second, the Governments should avoid taking extreme positions which are difficult to back down from. Third, the Governments can educate the public on the benefits and importance of joint development and the fact that it does not involve a surrender of sovereignty.

\section{Increase Understanding on Relevant Legal Issues}

International law may not determine the ultimate outcome of the South China Sea disputes as this in all likelihood will be fundamentally dependent on (geo)political factors. Nevertheless, international law will inevitably frame discussions and debate. The claimants are unlikely to accept a resolution or solution to the disputes that is contrary to generally accepted international law principles. Further, pending actual resolution of the South China Sea disputes, any actions or omissions by the claimants in relation to their claims in the South China Sea will be criticised and objected to if they are inconsistent with international law. 
However, despite the importance of international law to the disputes, the claimants appear to lack a proper understanding of the relevant international legal principles involved (or arguably choose not to place any emphasis on such principles). The Editors firmly believe that if the claimants were to obtain an objective and impartial analysis of the relevant international law from a neutral source, it would greatly enhance their understanding of the relative strengths and merits of their respective sovereignty and jurisdictional claims. Further, knowing what is permitted or not permitted under international law may also influence their conduct in the South China Sea. Ultimately, an enhanced understanding of the relevant international legal principles will allow the claimants to determine their bottom-line national positions in negotiations and may go a long way to facilitate a negotiated settlement of the South China Sea disputes. The Editors have identified three key areas in which enhanced understanding and knowledge of the legal issues would greatly benefit negotiations on the South China Sea disputes.

\section{A. The Role of Islands in Maritime Boundary Delimitation}

As mentioned in the Introduction, it is critical to place the islands and geographic features of the South China Sea in their true context, as irritants to maritime delimitation as opposed to being central to this process. In order to do this, the claimants must understand general maritime delimitation principles under international law, the way that ocean boundary-making has evolved and, in particular, the effect given to offshore features in maritime delimitation. 
While the UNCLOS provisions on the delimitation of EEZ and continental shelf boundaries are severely limited, ${ }^{7}$ containing no indication of a preferred method of delimitation, ${ }^{8}$ in practice the equidistance method has proved to be the dominant approach. Indeed, international courts and tribunals have developed an increasingly clear approach to the delimitation of EEZ and continental shelf boundaries, generally termed the 'equidistance/relevant circumstances approach'. 9 This essentially involves the construction of a provisional delimitation line based on equidistance and then consideration of any factors that may lead to an adjustment in that provisional line in order to yield an equitable result.

In this context, a clear trend has emerged with respect to the treatment of islands. That is if there are overlapping maritime claims between an EEZ measured from a small, remote island

\footnotetext{
${ }^{7}$ The principles of maritime delimitation are enshrined in Articles 74 and 83 of UNCLOS, which reflect customary international law; see Territorial and Maritime Dispute between Nicaragua and Colombia (Nicaragua v. Colombia), Judgment, ICJ Reports 2012 [Nicaragua/Colombia], at para 139; see also Maritime Delimitation and Territorial Questions between Qatar and Bahrain, Merits, Judgment (2001) ICJ Reports 40 [Qatar/Bahrain], at para 167.

${ }^{8}$ The general principle is that boundaries are to be delimited by agreement on the basis on international law in order to reach an equitable solution, see Continental Shelf (Libyan Arab Jarnahiriya/Malta) (1985) ICJ Rep. 13 [Libya/Malta], at 51; Eritrea v Yemen (1999) Award of the Arbitral Tribunal in the Second Stage of the Proceedings (Maritime Delimitation) at 116; Maritime Delimitation in the Black Sea (Romania v Ukraine) (2009) ICJ Rep 61 [Black Sea Case], at 120.

${ }^{9}$ Libya/Malta, ibid, at para 62; Qatar/Bahrain, supra note 7, at para 176; Black Sea Case, ibid, at paras 116 - 122; Dispute Concerning Delimitation of the Maritime Boundary between Bangladesh and Myanmar in the Bay of Bengal (2012) Judgment, ITLOS Case No 16 [Bangladesh/Myanmar] at para 455, online: ITLOS $<$ http://www.itlos.org/fileadmin/itlos/documents/press_releases_english/PR.140-E.pdf>.
} 
and an EEZ measured from the mainland or from an archipelagic State, the practice of courts and tribunals is to give a significantly reduced effect to the island when delimiting the maritime boundary. ${ }^{10}$

Moreover, at the time of writing, three recent cases involving maritime boundary delimitation, between Romania and Ukraine in the Black Sea before the International Court of Justice (ICJ) in 2009; ${ }^{11}$ between Bangladesh and Myanmar in the Bay of Bengal before the International Tribunal of the Law of the Sea in $2012 ;^{12}$ and between Nicaragua and Colombia in the Caribbean Sea before the ICJ in 2012, ${ }^{13}$ small islands have in fact been discounted from consideration in even in the construction of the provisional delimitation line. This serves to emphasise the point that small islands with limited coastal fronts and minimal to no population, located far offshore, tend to be awarded minimal impact on the delimitation of maritime boundaries. ${ }^{14}$ It can be strongly suggested that these developments have major implications for the potential role of disputed South China Sea islands in the delimitation of maritime boundaries, especially between such features and the surrounding mainland coastlines.

\footnotetext{
${ }^{10}$ Nicaragua/ Colombia, supra note 7, at para 140; see also Continental Shelf (Tunisia/Libyan Arab Jamahiriya), (1982) ICJ Reports [Tunisia/Libya], at para 73.

${ }^{11}$ Black Sea Case, supra note 8, at para 78.

${ }^{12}$ Bangladesh/Myanmar, supra note 9, at paras 318-319.

${ }^{13}$ Nicaragua/Colombia, supra note 7 , at para 140.

${ }^{14}$ See for example Maritime Delimitation in the Area between Greenland and Jan Mayen (Denmark v Norway)

(1993) ICJ Report 38 [Jan Mayen Case], at paras 61-69.
} 


\section{B. The Obligation to Limit Unilateral Activities in Disputed Areas}

As explored in Chapter $2,{ }^{15}$ one of the fundamental principles in UNCLOS with respect to overlapping maritime boundary claims is that the States concerned are under an obligation, in a spirit of understanding and cooperation, to make every effort to enter into provisional arrangements of a practical nature such as joint development arrangements or other cooperative measures. ${ }^{16}$ Such arrangements are without prejudice to the final delimitation of maritime boundaries or the resolution of the underlying sovereignty disputes. ${ }^{17}$

Furthermore, States have an obligation during this transitional period (when the provisional arrangements are in effect), not to take any unilateral actions which would jeopardize or hamper the reaching of a final agreement on the territorial and sovereignty disputes. ${ }^{18}$ This means that States are under an obligation not to take any unilateral actions which would permanently alter the situation in disputed areas. This includes unilateral drilling and the unilateral exploitation of resources.

\footnotetext{
${ }^{15}$ See Chapter 2: International Law, UNCLOS and the South China Sea by Robert C Beckman, at 63.

${ }^{16}$ UNCLOS, Articles 74(3) \& 83(3).

${ }^{17}$ Guyana/Suriname Arbitration, UN Law of the Sea Annex VII Arb Trib, award on 17 September 2007, at para 461, online: Permanent Court of Arbitration <http://www.pca-cpa.org/upload/files/Guyana-

Suriname\%20Award.pdf $>$; see also Ranier Lagoni, 'Interim Measures Pending Maritime Delimitation Agreements' (1984) 78 AJIL 345 at 358.

${ }^{18}$ Guyana/Suriname Arbitration, ibid, at para 480.
} 
It is not clear whether the claimants fully appreciate this international legal obligation to restrain their unilateral activities in areas in dispute. It in effect means that there can be no unilateral exploitation of the hydrocarbon resources in disputed areas. This casts a very serious cloud over the legality of any unilateral actions. The claimants and the oil companies should be made aware of this obligation of mutual restraint. Understanding this prohibition on unilateral exploitation will underscore the fact that joint development arrangements are the only way in which the claimants can acquire legitimate access to resources in certain areas of the South China Sea.

\section{Nature and Importance of Joint Development Arrangements}

There is a general lack of understanding on the nature of joint development arrangements. Many officials do not appear to understand that they can enter into joint development arrangements without compromising their sovereignty or maritime boundary claims and without recognizing the legitimacy of the claims of the other parties.

The key advantage of joint development is that it enables utilisation of the resources while at the same time preserves the sovereignty or maritime claims of the Parties. However, some officials or groups in the claimants perceive that such joint development arrangements will either compromise their sovereignty claims or be perceived as recognition of the legitimacy of the claims of the other claimants. Similarly, there is also a lack of understanding on, or perhaps a refusal to acknowledge, the importance of cooperation with regard to shared interests and / or shared resources. 
One of the ways in which such understanding can be enhanced is to organise seminars, workshops and other such meetings where such issues can be discussed and concerns raised. Such seminars, workshops and meetings can be organised by think tanks and research institutes on a 'Track Two' basis so as to encourage free and frank discussion. Given the role of the media in fanning the flames of nationalism, some of the sessions should include members of the media, provided of course, that the media does not sensationalize the issues under discussion.

\section{Reaching Agreement on the Areas for Joint Development}

A critical prelude to engaging in serious discussions on joint development arrangements is agreement on the specific geographic areas which are subject to overlapping maritime claims and might be subject to such joint mechanisms. For many joint development arrangements, the area of joint development reflects the area of overlapping EEZ or continental shelf claims. However, this issue is much more complicated in the South China Sea. At present, there is no clearly defined overlapping claim area which could be the joint development zone in a joint development arrangement and there is no agreement between the claimants on 'areas in dispute.' The following recommendations set out some options which would greatly facilitate agreement by the claimants on areas which could be subject to joint development.

\section{A. Encourage Claimants to Clarify Claims in accordance with 1982 UNCLOS}


As explained in Chapter 11, the co-operative arrangements in Asia demonstrate that one of the major factors conducive to joint development is the fact that the States involved had, in good faith, made defined maritime claims that had some legal basis under international law. At present, there is a significant lack of clarity on the basis, nature and extent of the maritime claims in the South China Sea, which has been discussed in Chapter 11.

It is therefore clear that all claimants should take steps to clarify their claims. This entails making clear what they are claiming and what is their legal basis for making such a claim. First, the claimants who are claiming a $200 \mathrm{~nm}$ EEZ from their mainland coast (or from their main archipelago in the case of the Philippines) should, if they have not already done so, give official notice of the outer limit of their EEZ by publishing charts or lists of geographic coordinates, as required by UNCLOS. In addition, if they have measured their $12 \mathrm{~nm}$ territorial sea and $200 \mathrm{~nm}$ EEZ from straight baselines along their coast, they should, if they have not already done so, give official notice of such baselines by publishing charts or lists of geographic coordinates, as required by UNCLOS. ${ }^{19}$

Second, the claimants should identify the names and locations of islands over which they claim sovereignty. This is important because States can claim sovereignty only over off-shore features which meet the definition of an island, and only islands are entitled to a territorial sea and other maritime zones. An island is defined as 'a naturally formed area of land, surrounded by water, which is above water at high tide.' Most of the geographic features in the South China Sea are reefs, shoals, cays or low-tide elevations which are not above water at high tide. One

\footnotetext{
${ }^{19}$ UNCLOS, Article 16.
} 
academic study concluded that less than $25 \%$ of the approximately 170 geographic features in the Spratly Islands meet the definition of an island. ${ }^{20}$

Third, if the claimant States believe that any of the islands they claim are entitled to an EEZ and continental shelf of their own, they should identify such islands and give notice of the EEZ claim from them by publishing official charts or lists of geographic coordinates of the limits of such claims, as required by UNCLOS. This is important because most of the islands in the South China Sea are tiny, uninhabitable rocks. Under UNCLOS, 'rocks which cannot sustain human habitation or economic life of their own' are not entitled to an EEZ or continental shelf. ${ }^{21}$

Notwithstanding this clarification, issues would remain on the status of the various features under UNCLOS and on how many of the features, if any, would be entitled to an EEZ and continental shelf of their own, and as mentioned above, this issue has not been definitively decided under international law. Nevertheless, such a clarification would be a major step toward reaching a consensus among the claimants on which areas in the South China Sea are in dispute and potentially subject to joint development arrangements, and which areas are not in dispute. Even if such a process would necessarily highlight differences and disputes among the claimants, nevertheless, it would enhance clarity and arguably contribute to the creation of an atmosphere of trust.

\footnotetext{
${ }^{20}$ For further details on the geographical description of the features in the Spratly Islands, see David Hancox \& Victor Prescott, 'A Geographical Description of the Spratly Islands and an Account of Hydrographic Surveys Amongst those Islands' (1995) 1:6 IBRU Maritime Briefings 1.

${ }^{21}$ UNCLOS, Article 121(3).
} 
Apart from clarification on the features in the South China Sea, China should also clarify what exactly the nine-dashed line means, that is, whether it is a claim to historical waters or historical rights or simply a line indicating the islands over which China has a sovereignty claim. Similarly, the exercise by China of rights and jurisdiction within the nine-dashed line, in areas far away from any of the features, puts China on a legal collision course with the ASEAN claimants as they believe that such a claim is not consistent with UNCLOS or general international law. This also makes it much more difficult to reach any consensus on the 'areas in dispute' which would be the subject of joint development arrangements, as the practical result would be that most of the South China Sea would be an area in dispute. It is highly likely that the clarification of the claims made in the South China Sea will, at the very least, increase the trust and confidence between claimants and provide a solid foundation for negotiations on joint development arrangements to proceed.

\section{B. Areas for joint development versus 'areas in dispute'}

While clarifying the claims will significantly contribute to determining areas in dispute, this may not occur for a long time. The question is whether the claimants would be able to negotiate 'areas for joint development' without identifying the areas in dispute.

If the status quo remains and the claimants, particularly China, do not clarify their claims such that it is not possible to identify an 'area in dispute', it may nonetheless still be possible for the claimants to reach agreement on the areas for joint development. Indeed, it is theoretically possible for the claimants to agree on areas for joint development without addressing the merits 
of the claims of China or of the other claimants. After all, the late Deng Xiaoping of China proposed that the claimants set aside the disputes and jointly develop the resources. ${ }^{22}$ Therefore, $^{2}$ it would be possible for the claimants to agree on areas for joint development which represented a compromise between China and the ASEAN claimants, without either side having to back down from their claims.

Identifying areas for joint development without definitively determining 'areas in dispute', however, may face some challenges. Some of the ASEAN claimants may well be resistant to such an approach. For example, the position of the Philippines has been that joint development or joint cooperation must be limited to the 'areas in dispute'. ${ }^{23}$ The Philippines' position seems to be that claims to maritime space can only be made by making claims to maritime zones from land territory or islands as set out in UNCLOS, and they challenge the legitimacy of any claim by China based on historic rights or sovereign rights within the ninedashed lines. Therefore, the Philippines' position is that much of its EEZ is not within an area in dispute and would not be an area for joint development. Their position seems to be that the only maritime areas in dispute within their EEZ would be the $12 \mathrm{~nm}$ territorial sea adjacent to the

\footnotetext{
${ }^{22}$ This concept was first openly advanced by Deng on 11 May 1979 in relation to China's dispute with Japan over Senkaku / Diao Yu Dao Islands, see 'Set Aside Dispute and Pursue Joint Development', 17 November 2000, online: Ministry of Foreign Affairs of the People's Republic of China $<$ http://www.fmprc.gov.cn/eng/ziliao/3602/3604/t18023.htm>.

${ }^{23}$ Albert F Del Rosario, 'Philippine Policy Response and Action' (Forum on 'The Spratly Islands Issue: Perspective and Policy Responses', delivered at the Department of Political Science, Ateneo De Manila University, 5 August 2011) online: Philippines Department of Foreign Affairs $<$ http://dfa.gov.ph/main/index.php/newsroom/dfareleases/3531--philippine-policy-response-and-action-by-the-hon-albert-f-del-rosario-secretary-of-foreign-affairs>.
} 
disputed islands within their EEZ. However, despite these obstacles, identifying areas for joint development instead of trying to get agreement on or identify 'areas in dispute' (which may be never) may be a convenient way to remove an otherwise potentially intractable impasse in negotiations of a joint development arrangement.

\section{Increase Knowledge of Features in the Spratly Islands}

If the claimants are to enter into discussions to define areas for joint development, it is likely that the discussions will take into account the nature of the disputed features in the Spratly Islands. The nature of the features is important to determine whether they are in principle subject to a claim of sovereignty and whether they are entitled in principle to an EEZ and continental shelf of their own.

As mentioned in Chapter $1,{ }^{24}$ the number and nature of the features in the Spratly Islands remains shrouded in mystery. While there are accounts of physical descriptions of some of the features made by geographers and academics, they are not up to date and not consistent with each other. The lack of definitive information on the number and nature of the features means that any discussion on the maritime zones that these features can generate under UNCLOS is mere speculation. This lack of knowledge contributes to the uncertainty and lack of clarity of the claims made by the claimants and also makes it difficult to identify disputed areas in which joint development can take place.

\footnotetext{
${ }^{24}$ See Chapter 1: What's at Stake in the South China Sea? Geographical and Geopolitical Considerations by Clive Schofield, at 15 .
} 
Accordingly, there should be further research on the features in the Spratly Islands. This could start with collating present information available and then verifying such information with satellite data. If neutral organisations or bodies carry out such research, the results are more likely to be taken into account by the claimants in any negotiations to define the areas for joint development.

A more radical and expensive but arguably more accurate approach would be to have physical surveys done of the Spratly Islands and information collected by qualified geographers. However, before any such research takes place, it should be supported or agreed to by the claimants, and be done on a 'without prejudice' basis.

It should be borne in mind that even if such research on the physical description of features is done, it would still be subject to a legal analysis on whether particular features meet the definition of an 'island' under Article 121(2) of UNCLOS capable of generating extended maritime claims (that is, EEZ and continental shelf rights) or is a sub-category of island ('rock') which cannot under Article 121(3) UNCLOS. To date, no reliable or accepted method of distinguishing between islands and rocks has emerged and Article 121 remains open to diverse interpretations. The potential role of such insular features in the delimitation of maritime boundaries would also necessarily then come in to focus (see above). Nonetheless, it would not be possible to even discuss the application of Article 121 to the features in the South China Sea unless information is available on the physical attributes of the features, notably including their size and whether they are above water at high tide. 


\section{Increase Knowledge of Nature and Location of Hydrocarbon Resources}

As explained in Chapter 11, estimates as to the seabed energy resource potential in the South China Sea vary wildly and are generally highly speculative in nature. Given that the South China Sea disputes are commonly perceived to be driven by the 'oil factor,' it is self-evident that the claimants should know what is at stake or in other words, what are they really 'fighting' for. While, as explained in Chapter 11, actual knowledge of hydrocarbon resources has the potential to make compromise more difficult, it can also add an impetus for States to enter into joint development arrangements, as they know that unilateral exploitation will be subject to protests and objections by the other claimants. Similarly, if it is discovered that there are no hydrocarbon resources in a certain area, it may also allow claimants to back down from initial hard-line or extreme positions. More practically, it will enable the claimants to know where the hydrocarbons are and hence, assist in identifying an area that could be suitable for joint development.

It may be the case that the claimants have some (or even extensive) data on hydrocarbon reserves in the South China Sea, acquired through unilateral seismic activities. However, such data does not appear to be publicly available and hence, is not helpful. Further, even if the data were made publicly available or were extended to other claimants, it will be open to the criticism that the data is not accurate or not properly acquired etc. Hence, the best-case scenario would be for joint seismic surveys to be done on a 'without prejudice basis'. 
There have been attempts to do joint seismic surveys by some of the claimants. The 2005 Joint Seismic Marine Undertaking (JMSU) between China, Viet Nam and Philippines was a very positive development even though it subsequently met with controversy and became mired in domestic politics in the Philippines. It is doubtful that the JMSU in its original form can be revived, particularly considering the opposition of the Philippines to the JMSU. Nonetheless, even if the 2005 JMSU cannot be revived, the ideas, principle and spirit of co-operation behind it can serve as a very useful model.

In light of this, joint seismic surveys between some or all the claimants done on a without prejudice basis in areas which are clearly in dispute would be a tremendous step towards joint development. The following points should be taken into account when negotiating an agreement for a joint seismic survey, based in part on lessons learned from the 2005 JMSU and from the existing co-operative arrangements in Asia:

1. The terms of any joint seismic survey should be fair and equal to all Parties and should be perceived as fair and equal. The area in which the joint seismic survey is done will play an important role in whether the joint survey is perceived as fair and equal. The fact that the JMSU covered an area too close to the Philippines territory of Palawan prompted protests that Philippines had compromised its sovereignty.

2. The Parties to the joint seismic survey should be the claimants which have bona fide claims made in good faith to the area in which the survey will be taking place. It should also involve all claimants which have claims in that area as possible so as to avoid 
protests and persistent challenges. For example, if there is an area which is claimed by China, Philippines and Viet Nam, all three States or their national oil companies should be Parties.

3. The agreement for the joint seismic survey should have robust 'without prejudice' clauses to allay concerns of States and their national populations.

4. The States concerned may wish to engage seismic survey companies which have no connection to or interest in the Spratly Islands disputes. Similarly, they may wish to use foreign-flagged vessels which have no connection to the States concerned. This will contribute to the perception of neutrality.

5. The States concerned should be allowed to have observers on board the survey vessels carrying out the survey.

6. The States concerned should be as transparent as possible in negotiations and in the actual agreement negotiated.

7. The States concerned should also manage the expectations of the public by emphasising how the survey does not prejudice their claims in any way.

It should, however, be emphasised that, as noted above, such surveys, even where they yield promising results, do not guarantee the presence of oil and gas in commercially exploitable 
quantities - only exploratory drilling can reveal this. That said, such surveys have the potential to move discussions on possible areas for joint development.

\section{E. Begin with Joint Development Arrangements in Small Areas with a Limited Number of Parties}

As explained in Chapter 11, it is much easier to conclude joint development arrangements when there are two parties. There are six parties to the South China Sea disputes and this is a considerable obstacle in concluding joint development arrangements. However, if the claimants follow the advice of Hasjim Djalal of Indonesia, they will begin with the easy cases, or in ASEAN-speak the 'low hanging fruits'. ${ }^{25}$

It may be easier to begin the process in an area where there are only two or three Claimant States. Indeed, some areas of the South China Sea are claimed only by two States. For example, parts of the northwestern South China Sea are claimed by Viet Nam and China alone. These States have already reached agreement on their land boundary and on their maritime boundary in part of the Gulf of Tonkin. Therefore, it is not inconceivable to suggest that they may be able to reach agreement for joint development in a small area claimed by only those two States. One area which might be considered is the area in the Gulf of Tonkin itself which is already subject to a joint arrangement regarding fisheries resources. Another possible area is near Vanguard Bank, outside the EEZ claim of Viet Nam, near Spratly Island, although admittedly

\footnotetext{
${ }^{25}$ Hasjim Djalal, Preventive Diplomacy in Southeast Asia, (Jakarta: The Habibie Center, 2003) and Hasjim Djalal,
} 'Conflict Management Experiences in Southeast Asia: Lessons and Implications for the South China Sea Disputes' 2011 3(4) Asian Politics \& Policy, 627-642. 
this may be less likely given its proximity to disputed features. The cooperative arrangement could begin with a joint seismic survey between the national oil companies of the two countries and then lead to a joint development arrangement to further explore and exploit the resources. If China and Viet Nam could agree to a joint development arrangement in one of these areas, it could serve as a model for joint development arrangements in other areas in the South China Sea.

Another possibility is for China and the Philippines to agree to a joint development arrangement on fisheries resources in the waters adjacent to Scarborough Shoal. Although relating to fisheries resources rather than hydrocarbons, a joint development or co-operation arrangement in the waters surrounding the Scarborough Shoal may be feasible in light of the fact that this area is also claimed by only two States, China and the Philippines. The major features of a joint development arrangement on fisheries could be used as a model for joint development arrangements on hydrocarbon resources in other areas.

Most of the larger islands which are in dispute are inside or just outside the Philippines' claim to the islands in the Kalayaan Island Group. These islands are also claimed by China and Viet Nam. Therefore, these three claimants, or their national oil companies, could undertake action in a small area in the territorial sea adjacent to several of the disputed islands. They could agree to undertake joint seismic surveys in this area and to share the data, and they could specifically agree that the arrangement is without prejudice to the sovereignty disputes or to the eventual delimitation of maritime boundaries. Negotiations for such arrangements could be done directly by the concerned claimants, or through mediators. 
At this point, it is appropriate to mention Taiwan. Taiwan is a claimant to the Spratly Islands dispute but is not recognised by the international community as a State. Also, China is reluctant to allow Taiwan to enter into negotiations as an equal party as it could imply that it is a State. Since the ASEAN States follow a one-China policy, the role of Taiwan in any joint development arrangements must be decided between China and Taiwan. Negotiations on the joint development of hydrocarbons could proceed without Taiwan so long as it did not include the area adjacent to the island of Itu Aba, which is occupied by Taiwan.

It should be absolutely clear that discussions to establish any of these arrangements are undertaken without prejudice to the underlying sovereignty disputes and maritime claims of the claimants. One of the benefits of joint development arrangements is that the claimants concerned can agree on joint cooperation arrangements in a specific defined area without any of them having to give up or clarify their claims to geographic features or maritime space.

\section{Reaching Agreement on Other Provisions in Joint Development Arrangements}

Arguably, agreements on an area for joint development and the parties to a joint development arrangement (both of which are dependent on each other) are the main obstacles in negotiations on a joint development arrangement in the South China Sea. However, agreement on other provisions of a joint development arrangement will also need to be negotiated. While examining the existing co-operative arrangements in Asia was useful in setting out the issues and considerations that need to be addressed in any joint development arrangement, it also demonstrated that each joint development arrangement is unique, and that the precise terms of 
any joint development arrangement will depend on the particular needs and circumstances of the States at the time. Accordingly, this Volume does not intend to advocate any particular framework for the management of resources in a joint development arrangement for the South China Sea, be it a simple agreement between national oil companies or a more comprehensive structure establishing a joint authority. However, the following recommendations will facilitate negotiations on an appropriate institutional framework for a joint development arrangement.

\section{A. Conduct Research on Joint Development Regimes Suitable for the South China Sea}

It may facilitate joint development if more research were done on joint development regimes that would be the most suitable for the specific and unique situation in the South China Sea. Such research can be done by independent experts, lawyers, think tanks or research institutions which are neutral and have no interest or connection to the disputes in the South China Sea. Analysis could begin by focusing on the main provisions in a joint development agreement that need to be decided, that is, the area in which the joint development should take place, the parties to such an agreement and the necessary institutional framework for management of the resources. Consideration of joint development regimes should also be done with the input and involvement of the claimants on a non-binding and 'without prejudice' basis.

If the claimants were to actually see how and / or on what terms joint development can be done in real terms (as opposed to the abstract way joint development has been discussed until now), it would significantly enhance the chances of them coming to an agreement on joint 
development. While the joint development regime put forward would not bind the claimants in any manner, it would provide an excellent starting-point for negotiations.

\section{B. Involve Oil Companies in the negotiations}

Oil Companies (both state-owned and privately owned) could have a significant role to play in facilitating joint development in the South China Sea. They are the contractors who will ultimately be carrying out exploration and exploitation and will be required to provide considerable capital input. It may be useful for the claimants to engage oil companies in the discussions for joint development arrangements. This is especially so if oil companies have been granted licenses to conduct seismic surveys in petroleum blocks in or near the area being considered for joint development.

Oil companies may also be in the best position to advise on the provisions best suited to a joint development arrangement in the South China Sea and can also facilitate joint development is through education and dialogue with the claimants on the benefits of joint development and on technical matters related to joint development (such as licensing regimes, petroleum laws, safety of installations). This would not only enhance understanding on joint development but also improve the lines of communication between the claimants and oil companies.

\section{Conclusions}


Overall, joint development arrangements offer a potentially highly attractive option to circumvent disputes and proceed with management and development activities in broad maritime areas subject to competing claims. When considering the potential merits of joint development arrangements, however, the potential downsides of joint development should not be lightly dismissed. Further, mere agreement on the joint development of seabed energy reserves does not mean that such resources will inevitably be discovered. The majority of the joint development arrangements in Asia, such as the 1979 / 1990 Malaysia-Thailand Arrangement, ${ }^{26}$ the 1992 Malaysia-Viet Nam Arrangement ${ }^{27}$ and the 1989 Australia-Indonesia Arrangement ${ }^{28}$ have been successful in the exploration and exploitation of hydrocarbon resources in the Joint Development

${ }^{26}$ Memorandum of Understanding between Malaysia and the Kingdom of Thailand on the Establishment of a Joint Authority for the Exploitation of the Resources in the Sea-Bed in a Defined Area of the Continental Shelf of the Two Countries in the Gulf of Thailand, 21 February 1979 (entered into force 24 October 1979) and Agreement between the Government of Malaysia and the Government of the Kingdom of Thailand on the Constitution and Other Matters relating to the Establishment of the Malaysia-Thailand Joint Authority, 30 May 1990 [1990 Malaysia-Thailand Agreement], both reprinted in David M Ong, 'The1979 and 1990 Malaysia-Thailand Joint Development Agreements: A Model for International Legal Co-operation in Common Offshore Petroleum Deposits?', (1999) 14:2 Int'1 J Mar \& Coast L 207, at 61.

${ }^{27}$ Memorandum of Understanding between Malaysia and the Socialist Republic of Viet Nam for the Exploration and Exploitation of Petroleum in a Defined Area of the Continental Shelf Involving the Two Countries, 5 June 1992 (entered into force 4 June 1993), reprinted in Charney \& Alexander, eds, International Maritime Boundaries, vol 3 (Martinus Nijhoff Publishers, 1998) at 2335.

${ }^{28}$ Treaty between Australia and the Republic of Indonesia on Zone of Co-operation in an Area between the Indonesian Province of East Timor and Northern Australia, 11 December 1989, [1991] ATS 9 (entered into force 9 February 1991). 
Zones. However, with regards to the 1974 Japan-South Korea Arrangement, ${ }^{29}$ there have been no discoveries of commercially viable oil and gas reserves, although Japan and South Korea have recently decided to resume joint surveys.

Notwithstanding the above, perhaps the most pertinent question is this: what is the alternative? Joint development arrangements seem all the more attractive when considering the alternatives for resolution of the South China Sea disputes. First, unfortunately it appears readily apparent that a resolution of the sovereignty disputes and maritime delimitation issues in the South China Sea is highly unlikely either in the immediate or near future, whether through third party dispute settlement or bilateral or multilateral negotiations.

Second, in terms of conflict management and prevention, the terms of the 2002 DOC, while a significant milestone, has not been implemented. In particular, the potentially valuable confidence-building and tension-reducing measures outlined in the DOC have not been realised. While there is some positive progress in that Guidelines on Implementation were agreed upon in July 2011, that it took almost a decade to achieve even this preliminary step towards implementation does not offer strong grounds for confidence in the capacity of the DOC as a means to manage the South China Sea disputes. Further, although there are presently on-going discussions between ASEAN and China on a legally binding code of conduct (COC) in the South China Sea, actual agreement on this appears to be a long way off. Moreover, the COC (as well as

\footnotetext{
${ }^{29}$ Agreement between Japan and the Republic of Korea Concerning Joint Development of the Southern Part of the Continental Shelf Adjacent to the Two Countries, 30 January 1974, 1225 UNTS 114-126(1981).
} 
the 2002 DOC for that matter) will not address the underlying sovereignty and maritime disputes.

While it is likewise the case that joint development does not address the underlying territorial and maritime jurisdictional disputes, nonetheless this option offers multiple distinct advantages. Of especial note, entering into a joint development arrangement as a 'provisional arrangement of a practical nature' is an accepted legal option, warranted under UNCLOS and recognized by international courts and tribunals as an equitable solution to overlapping maritime claims. Such joint mechanisms also represent a functional necessity to enable utilization of resources in disputed areas whilst simultaneously, and critically, being without prejudice to existing claims.

In short, continued deadlock regarding overlapping maritime claims and failure to enter into joint arrangements means that any seabed energy resources that underlie disputed waters will necessarily remain there and be of no benefit to any of the States involved. Further, without joint, cooperative arrangements, maritime disputes will remain an ongoing source of inter-State friction and contention. This, in turn, is likely to have negative, even disastrous, implications for relations between the States concerned and, ultimately, threaten international peace and security. 